\title{
Jinn and its Effects on Muslim Society
}

\author{
Jilani ben Touhami Mefah* \\ Universiti Islam Sultan Sharif Ali,Simpang 347, Jalan Pasar Baharu, Gadong Bandar Seri Begawan BE1310, Brunei Darussalam,Asia
}

Submission: August 31, 2018; Published: September 20, 2018

*Corresponding author: Jilani ben Touhami Mefah, Universiti Islam Sultan Sharif Ali,Simpang 347, Jalan Pasar Baharu, Gadong Bandar Seri Begawan BE1310, Brunei Darussalam,Asia, Email: jil.meftah@gmail.com

\begin{abstract}
Muslims believe that there are unseen beings called jinn. Their world exists in parallel to that of the human world. Indeed, these creations are powerful, move fast, and can easily change shape. Due to the mixture of this belief with local cultures, most Muslims believe that jinn are responsible for many psychological, mental and physical diseases and they are even responsible for social problems. As a result, religious healers present themselves to deal with this perceived phenomenon and treat its effects on the individuals and groups. This present review provides a general overview of this belief, the effect of jinn on humans and the way they treated them.
\end{abstract}

Keywords: Jinn; Human; Religious healers; Patient, Belief; Culture; Effect; Scorching fire; Muslim

\section{Introduction}

Muslims believe in the existence of the unseen world, which generally includes besides angels, Satan, the hereafter, heaven, hell and jinn. This belief is based on many verses from the Quran, which mention that jinn are one of Allah's creations: "and the jinn we created before from scorching fire" (Saheeh International: 34:14). In fact, followers of other major religions believe also in the effect of demons, witchcraft, and the evil eye. It is not an exaggeration to say that approximately $90 \%$ of the world's societies believe in demonic possession [1]. Nevertheless, among these unseen creations, Jinn are most in competition with human beings, as they share with them many characteristics and attributes. They can think, eat, marry, love, hate, be angry or happy in addition to having free will. "Jinn, good or bad due to their beneficial or harmful effects could be believers or nonbelievers in Allah and could take any shape and form" [1]. However, in comparison to humans, jinn are more powerful. Jinn can move fast and travel huge distances [2], shape and reshape in many different forms and the most dangerous attribute is that they can possess man's mind and body [3]. Thus, most of "the followers of Islam believe in jinn who can see and watch humans and bedevil them" [1].

\section{Jinn Effect on Human Being}

Despite their belief in the existence of Jinn, Muslims religious scholars and thinkers have differing opinions on their effect on human beings. This is because there is no text from the Quran or the authentic Prophet tradition that mentions that clarifies this explicitly. According to some, it is impossible that Jinn can possess someone's body, affect him with any sickness, or cause any harm. To them the real Satan is a person's own soul. If he believes in something than it seems to him to be true where it is a mere illusion caused by rage and bad desire. Hence, they conclude that there is no link between humans and Jinn [4]. In the other hand, the other group believes that Jinn can possess people's body, affect them and cause them sickness. Jinn also can possess human for love and sex and they can even marry each other and have children. Due to Ibnu Taimiyyah and his modern followers, this is a well-known fact [5]. According to this group, anyone who denies the belief in Jinn's effect on humans is denying what Allah said [6] and he is an atheist [3].

\section{Reasons why Jinn affect Human Being}

According to the believers in Jinn's affect, there are many reasons why Jinn disturb humans. It can be revenge when someone disturbs them either by urinating or pouring hot water on them [5]. It can be because the Jinn admire and have a very strong sexual desire for that person, so it wants to clinch its lust with him/her [5]. It can be also because of other things such as anger, uncontrolled emotions, fear and following desires [6].

\section{How can Religious Healers (Rhs) Control Jinn?}

The believers in Jinn affects claim that human beings can communicate with Jinn and even exploit them for some purpose such as pilgrimage or freeing obsessed body or even using them to kill other Jinn [7]. They explain this with the story in the Quran, which tells that Prophet Solomon had employed Jinn and exploited them. They depend in their argumentation on a narration saying that one night while the Prophet Muhamad was praying, a nutty Jinn disturbed him, then he (the prophet) caught the Jinn and attempted to tie it to the mosque pillar until morning, but he didn't succeed [6].

\section{Stages of how Religious Healers Treat their Patients}

One the most popular way that RHs treat their patients consists of three stages: 


\section{Before Starting the Treatment: in This Stage, the RH Must}

a. Clean off the place from pictures to allow angels enter the place.

b. Burn any amulets with the patient.

c. Clean the place from any musical instrument.

d. Evocate the place from any prohibited manner; such as man wearing gold ring or unveiled women.

e. Give the family of patient a lesson in the pure Islamic aquidah (salafi version).

f. Diagonize the patient by asking him/her some questions such as did he/she have any bad dream such as to be attacked by animals or falling from high or walking alone in a scary place. These types of questions and diagonaze should continue until the $\mathrm{RH}$ is sure about the type of Jinn and their number. For example, if she/he saw many snakes it means many Jinns possess him/her.

\section{The HR Put his Hand on the Head of Patient then}

a. Recite in his/her ear certain chosen verses from the Quran that are special for this purpose; they include first chapter (fatiha) and all verses mentioned about Jinn. Doing this will force the Jinn to evocate the patient body or force him be nervous and speak.

b. Signs of the presence of Jinn; closing the eyes, shivering, screaming and maybe telling its name.

c. Start asking it (Jinn) questions about its name, his religion, in which part of the body it is located and is it alone or with other Jinn.

d. If it is Muslim, ask it to fear Allah, give Salam and go out safely but if it is non-Muslim, tell it first about Islam then ask it to go out, if it does not want, force it by snapping it and reciting verses of Jinn until it agrees to leave.

After the treatment, the patient needs special care because he/she is subject to the return of Jinn, thus he/she must keep reading Quran regularly, pray on time and only associate with good people [3].

\section{Assessment}

The problem is not in the belief in the existence of Jinn, which is mentioned by the Quran. Indeed, some researchers claim that Jinn are scientifically proved. The problem is in deliberately attributing this belief to the Quran and Sunnah and turning it to a belief matter. Where is in contrary, there is little detailed description of jinn in the Qur'anic and Prophetic literature. Instead, the Quran stressed about the weakness of Jinn. They are stupid and ignorant; they remained in humiliation for years and could not realize the death of their humiliator: "And when We decreed for Solomon death, nothing indicated to the jinn his death except a creature of the earth eating his staff. But when he fell, it became clear to the jinn that if they had known the unseen, they would not have remained in humiliating punishment" (Saheeh International: 34:14).

No doubt, that the belief in Jinn affects hides an iceberg of cultural and social problems. People in the Muslim world are subject to cultural and social oppression. They are mostly deprived of many basic rights; there are many cultural and social taboos that limits his/her right of choice and expression. Culturally, in some Arab countries people are still not able to admit their sexual impotence. Thus, if someone face such problem, the belief in Jinn will be a good rescue for him/her to justify such problem and avoid society blame and harassments. A woman in Dubai restrained herself from sleeping with her groom. Later she was able to convince the court to divorce her from him due to the reason that Jinn prevent her from having sex [8]. In this case no one can blame her, all people will surround to the Jinn belief. Another girl said that Jinn rape her and due to that, she lost her virginity [9]. By blaming Jinn, the girl will be safe from blame and punishment and may be will get sympathy instead, because Jinn is beyond control. A man in Egypt killed his mother and claimed that Jinn order him to kill her. Later the court found out that the real reason is heritage [10].

\section{Conclusion}

The belief in such spiritual forces on man is an old illusion that is passed on from one generation to another and it encompasses most world religion followers. Due to some cultural and social factors especially in the Muslim world, this belief turns to a main vehicle for many individuals to justify their problems and failure. The question that needs to be answer is how to free Muslims from this mythology, its factors and effects and make them seek really cultural and social changes?

\section{References}

1. Al-Habeeb TA (2012) A pilot study of faith healers' views on evil eye, jinn possession, and magic in the Kingdom of Saudi Arabia. J Fam Community Med 10: 31-38.

2. Makhmoor Talat (2017) The Jinn: Islamic view about them p. 2.

3. Bali, Wahid Abdussalam (2003) Wiqayah al-Ins mina al-Jinn wa alshaitan. Maktabah al-Tabi'in, Cairo, Egypt, Maktabah al-sahabah, Dubai, Emirates p. 29-86.

4. Al-Razi, Muhamad Ibn Omar (1999) Mafatih al-Gaib. Dar al-'Ihya alTurath al-Arabi, Beiru, Lubnan 19: 85-86.

5. Ibin Taimiyyah A (1995) Majmou3 al-Fatawa, edited by: Abdurrahman IbnMuhammad, King Fahd Complex for the Printing of the Holy Quran. Madinah, Saudi Arabia 19: 39-40.

6. Muhamad al-Zubair, Isra' al-Sai'id (2016) Al-Iman bi Alim al-Jinn wa Atharuhu ala al-Muslim. The National Ribat University, Sudan p. 17-53.

7. Muhamad, Abdulqadir (2011) Hukum al-Isti'ana bi al-Jinn fi alMubahat. Umm al-Qura University, Makka, Saudi 8: 52.

8. Nahil, Abdullah (2014) Mass Mina al-Jinn Yatasabbab fi Talaq zawjah.

9. Anwar, Lamis (2015), Igtasabani wa Ana Na'imah, Kabos, Poland, Europe.

10. Ali Salim (2016) Al-Muttaham bi Qatli Walidatih bi Mansha'ah alQanatir: al-Jinn Qalalli Uqtulha ala Shan hata'khuth warthik, al-Yawm al-Sabi. 
(C) This work is licensed under Creative BY DOI: 10.19080/GJAA.2018.06.555694
Your next submission with Juniper Publishers will reach you the below assets

- Quality Editorial service

- Swift Peer Review

- Reprints availability

- E-prints Service

- Manuscript Podcast for convenient understanding

- Global attainment for your research

- Manuscript accessibility in different formats

( Pdf, E-pub, Full Text, Audio)

- Unceasing customer service

Track the below URL for one-step submission https://juniperpublishers.com/online-submission.php 